\title{
Evaluasi Nilai Distribusi Beban As Kendaraan Berdasarkan Data Aktual di Lapangan untuk Kendaraan dengan Konfigurasi Sumbu 1.2 H dan 1.2+2.2
}

\author{
Renna Melinda ${ }^{1, *}$, Catur Arif Prastyanto ${ }^{1}$ \\ Departemen Teknik Sipil, Institut Teknologi Sepuluh Nopember, Surabaya \\ Koresponden*, Email: renna.melinda9@gmail.com
}

\begin{tabular}{lll}
\hline \multicolumn{1}{c}{ Info Artikel } & Abstract \\
\hline $\begin{array}{ll}\text { Diajukan } 04 \text { Februari } 2019 \\
\text { Diperbaiki } 07 \text { Februari } 2019 \\
\text { Disetujui } 08 \text { Februari } 2019\end{array}$ & $\begin{array}{l}\text { In Indonesia there are many cases of road damage before the durability of the plan is reached. } \\
\text { One influential factor is that there are many overloaded trucks. To plan pavement thickness } \\
\text { refers to the method of flexible pavement planning issued by the Bina Marga. Whereas the data } \\
\text { contained in these guidelines are only for vehicles with a standard charge. Inappropriate } \\
\text { conditions are thought to affect the load distribution value of the vehicle. The data used in this } \\
\text { study is Weight in Motion (WIM) data on several provincial roads in the East Java region. To } \\
\text { prove the validity of the hypothesis, the independent average hypothesis test analysis method is } \\
\text { used. From the results of the average test it can be concluded that there are differences in the } \\
\text { value of the distribution of research results with Bina Marga which influences the EAL value. } \\
\text { The difference in EAL values due to overloading varies between } 3.40 \text { times and } 3.49 \text { times } \\
\text { greater than the standard load. This can affect the planning of flexible pavements, thus causing } \\
\text { the pavement performance to be less optimal and to experience early damage. }\end{array}$ \\
$\begin{array}{l}\text { Keywords: Equivalent Axle Load (EAL), } \\
\text { overloaded, vehicle axis loads distribution, } \\
\text { Weight in Motion (WIM) }\end{array}$
\end{tabular}

\begin{abstract}
Abstrak
Di Indonesia banyak terjadi kasus kerusakan jalan sebelum umur rencana. Salah satu faktor yang berpengaruh adalah banyak truk bermuatan overloaded. Untuk merencanakan tebal perkerasan mengacu pada metode perencanaan perkerasan jalan lentur yang dikeluarkan oleh Dinas Pekerjaan Umum Bina Marga. Sedangkan data yang ada pada pedoman tersebut hanya untuk kendaraan dengan muatan standar. Kondisi yang kurang sesuai tersebut diduga akan mempengaruhi nilai distribusi beban as kendaraan. Data yang digunakan dalam penelitian ini adalah data Weight in Motion (WIM) di beberapa ruas jalan provinsi di wilayah Jawa Timur. Untuk membuktikan kebenaran hipotesa digunakan metode analisis uji hipotesis rata-rata independen. Dari hasil uji rata-rata tersebut disimpulkan bahwa terdapat perbedaan nilai distribusi hasil penelitian dengan Bina Marga yang berpengaruh terhadap nilai EAL. Perbedaan nilai EAL akibat kelebihan muatan bervariasi antara 3.40 kali sampai dengan 3.49 kali lebih besar dari muatan standar. Hal tersebut dapat mempengaruhi perencanaan perkerasan lentur, sehingga menyebabkan kinerja perkerasan kurang optimal dan mengalami kerusakan dini.
\end{abstract}

Kata kunci: Equivalent Axle Load (EAL), muatan berlebih, distribusi beban as kendaraan, Weight in Motion (WIM) maka akan meningkatkan nilai damage factor (DF) sehingga menyebabkan jalan mengalami kerusakan dini dan mengurangi performa jalan tersebut dalam melayani lalu lintas pada umur rencana.

Menurut Yoder, dkk [2] kerusakan jalan terdiri dari dua bagian, yaitu kerusakan struktural dan kerusakan fungsional. Kerusakan struktural adalah hancurnya satu atau beberapa lapisan struktur perkerasan sehingga tidak mampu lagi untuk memikul beban lalu lintas. Sedangkan kerusakan fungsional adalah, kerusakan yang timbul pada permukaan jalan sehingga mengurangi tingkat kenyamanan berkendaran dan keamanan bagi pengguna jalan.

Perbedaan umur aktual dengan umur rencana diduga terjadi karena kesalahan saat menentukan parameter dalam perencanaan tebal perkerasan. Dalam hal ini adalah persentase distribusi beban as kendaraan. Diduga nilai persentase 
distribusi beban sumbu kendaraan yang ada pada pedoman Bina Marga kurang sesuai dengan kondisi aktual saat ini. Mochtar[3] berpendapat bahwa cara perencanaan tebal perkerasan lentur oleh Bina Marga 1987 kurang memperhitungkan adanya muatan kendaraan berat yang sebagian besar overloaded dan hanya mengasumsikan bahwa truk bermuatan normal atau hanya slightly overloaded (bermuatan agak diatas normal). Berdasarkan penelitian yang dilakukan oleh
Prastyanto[4] disebutkan bahwa nilai distribusi beban dengan Bina Marga 1987 terdapat hasil yang berbeda. Prastyanto menyebutkan perbedaan nilai EAL adalah sebesar 2,2 sampai dengan 8,3 kali lebih besar dari Bina Marga. Hal ini terjadi karena, untuk truk dengan beban overloaded mempengaruhi nilai distribusi beban. Penelitian yang dilakukan oleh Prastyanto[4] dapat dilihat pada Tabel 1.

Tabel 1. Hasil nilai EAL untuk truk dengan konfigurasi sumbu 1.2+2.2

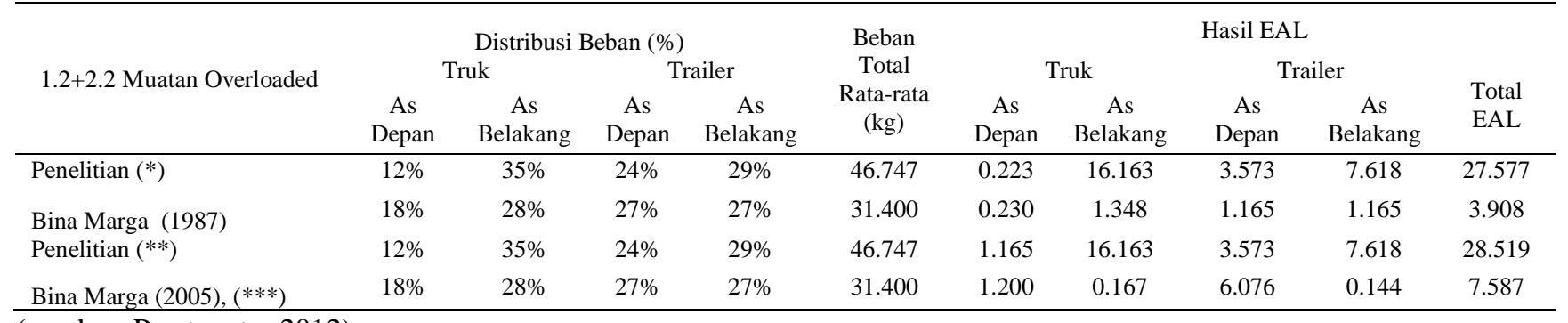

(sumber: Prastyanto, 2012)

Catatan:

$(*) \quad=$ Kalkulasi EAL berdasarkan Bina Marga (1987)

$(* *)=$ Kalkulasi EAL berdasarkan Bina Marga (1987)

$(* * *)=$ Data beban total untuk kalkulasi EAL berdasarkan Bina Marga (1987)

Pada Manual Desain Perkerasan Jalan[5] dengan beban as standar yang sama dengan Bina Marga (2005), terdapat dua nilai pangkat yang diusulkan yaitu nilai pangkat 4 dan pangkat 5. Penggunaan nilai pangkat 4 adalah untuk pelaburan lapis tipis (Burda) dan perkerasan tanpa penutup. Sedangkan untuk nilai pangkat 5 adalah untuk perkerasan jalan lentur.

\section{Metode}

Data yang digunakan dalam penelitian ini adalah data WIM (Weight in Motion) dari hasil survey kendaraan berat di 11 ruas jalan provinsi di Provinsi Jawa Timur. WIM adalah sebuah metode pengukuran beban kendaraan yang dapat dilakukan ketika kendaraan bergerak. Data yang didapatkan dari survey tersebut meliputi nilai beban gandar (axle weight) dan beban total (gross wight). Survey tersebut dilakukan di ruas jalan provinsi di Provinsi Jawa Timur, oleh Dinas Pekerjaan Umum Bina Marga provinsi Jawa Timur pada tahun 2017. Peta wilayah dan jaringan jalan Provinsi Jawa Timur dapat dilihat pada Gambar 1.

Dalam penelitian ini, perhitungan nilai distribusi didasarkan pada penggunaan nilai pangkat 5 yang ditujukan untuk perkerasan jalan lentur. Kendaraan yang ditinjau adalah truk dengan konfigurasi sumbu 1.2H dan 1.2+2.2 Untuk menentukan nilai distribusi diperlukan perhitungan VDF dengan menggunakan Persamaan (1), sedangkan nilai beban standar sesuai pada Tabel 2.

$V D F=\left[\frac{P}{P s t d}\right]^{b}$

Dimana,

VDF : faktor daya rusak kendaraan

$\mathrm{P} \quad$ : beban as gandar kendaraan (ton)

Pstd : beban as gandar standart (ton)

b : nilai pangkat pada persamaan EAL

Tabel 2. Beban standar untuk masing-masing as kendaraan

\begin{tabular}{ccc}
\hline No & Jenis Beban as kendaraan & $\begin{array}{c}\text { Beban as } \\
\text { kendaraan } \\
\text { (ton) }\end{array}$ \\
\hline 1 & STRT (Sumbu Tunggal Roda Tunggal) & 5,4 \\
2 & STRG (Sumbu Tunggal Roda Ganda) & 8,16 \\
3 & SGRG (Sumbu Ganda Roda Ganda) & 13,76 \\
4 & STrRG (Sumbu Tridem Roda Ganda) & 18,45
\end{tabular}

Untuk menguji perbandingan nilai distribusi antara hasil penelitian dan Bina Marga maka diilakukan dengan uji ratarata dua sampel independen. Langkah-langkah uji rata-rata dua sampel independen sebagai berikut:

Uji Hipotesis

H0 : Tidak ada perbedaan, tidak berpengaruh terhadap nilai EAL 
$\mathrm{H} 1$ : Terdapat pebedaan, berpengaruh terhadap nilai EAL

Jika P-value < alfa $(\alpha)$, Maka H0 ditolak, H1 diterima.

$\mathrm{H} 0: \mathrm{X} 1=\mathrm{X} 2$

$\mathrm{H} 1: \mathrm{X} 1 \neq \mathrm{X} 2$

Membandingkan dengan taraf signifikan, alfa $(\alpha)=0,05$

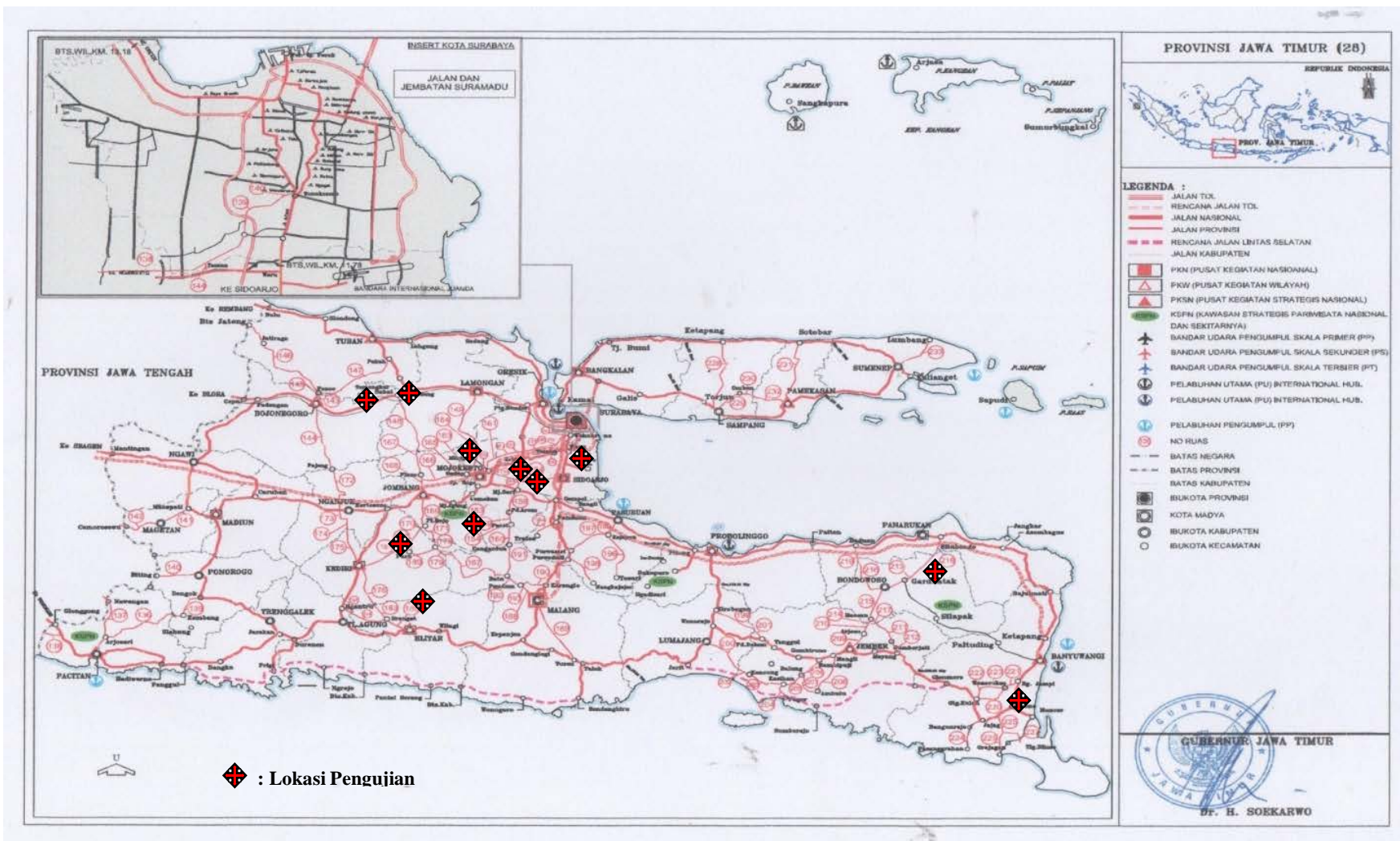

Gambar 1. Peta Wilayah dan Jaringan Jalan Provinsi Jawa Timur Sumber: Bina Marga Provinsi Jawa Timur

\section{Hasil dan Pembahasan}

Nilai distribusi digunakan untuk menentukan rumusan EAL. Dalam perumusan EAL terlebih dahulu dilakukan perhitungan nilai VDF untuk masing-masing beban kendaraan menggunakan Persamaan (1).

Kendaraan golongan $1.2 \mathrm{H}$ umumnya berupa kendaraan truk berat dengan muatan pasir, tanah, besi, semen dan memiliki 2 sumbu. Dengan sumbu depan termasuk jenis sumbu tunggal roda tunggal (STRT) dan sumbu belakang termasuk jenis sumbu tunggal roda ganda (STRG). Pada penelitian ini jumlah truk $1.2 \mathrm{H}$ dengan muatan overloaded sebanyak 41 truk. Maka perhitungan nilai VDF untuk truk $1.2 \mathrm{H}$ adalah sebagai berikut,
VDF sumbu $1=\left[\frac{3320 / 1000}{5,4}\right]^{5}=0,0878$

$E A L$ sumbu $1=\frac{V D F 1+V D F 2+\ldots \ldots \ldots \ldots \ldots . . V D F 41}{n}=1,9541$

$V D F$ sumbu $2=\left[\frac{10720 / 1000}{8,16}\right]^{5}=3,9131$

EAL sumbu $1=\frac{V D F 1+V D F 2+\ldots \ldots \ldots \ldots \ldots . . V D F 41}{n}=10,499$

Untuk lebih lengkapnya, perhitungan VDF dari masingmasing kendaraan dapat dilihat pada Tabel 3. 
Tabel 3. Distribusi beban as dan nilai EAL untuk truk $1.2 \mathrm{H}$

\begin{tabular}{|c|c|c|c|c|c|c|c|c|c|c|c|c|c|}
\hline \multirow{3}{*}{ No } & \multicolumn{3}{|c|}{ Trailer truck } & \multicolumn{3}{|c|}{ Hasil EAL } & \multicolumn{4}{|c|}{ Trailer truck } & \multicolumn{3}{|c|}{ Hasil EAL } \\
\hline & \multicolumn{3}{|c|}{ Distribusi Beban As (kg) } & \multicolumn{3}{|c|}{ Bina Marga 2005} & \multirow{2}{*}{ No } & \multicolumn{3}{|c|}{ Distribusi Beban As (kg) } & \multicolumn{3}{|c|}{ Bina Marga 2005} \\
\hline & $\begin{array}{c}\text { As } \\
\text { Depan }\end{array}$ & $\begin{array}{c}\text { As } \\
\text { Belakang }\end{array}$ & Total & $\begin{array}{c}\text { As } \\
\text { Depan }\end{array}$ & $\begin{array}{c}\text { As } \\
\text { Belakang }\end{array}$ & Total & & $\begin{array}{c}\text { As } \\
\text { Depan }\end{array}$ & $\begin{array}{c}\text { As } \\
\text { Belakang }\end{array}$ & Total & $\begin{array}{c}\text { As } \\
\text { Depan }\end{array}$ & $\begin{array}{c}\text { As } \\
\text { Belakang }\end{array}$ & Total \\
\hline 1 & 3320 & 10720 & 14040 & 0.0878 & 3.9131 & 4.0010 & 21 & 4160 & 13240 & 17400 & 0.2713 & 11.2458 & 11.5171 \\
\hline 2 & 5320 & 8840 & 14160 & 0.9281 & 1.4921 & 2.4202 & 22 & 4400 & 13320 & 17720 & 0.3592 & 11.5897 & 11.9488 \\
\hline 3 & 3840 & 10400 & 14240 & 0.1818 & 3.3629 & 3.5448 & 23 & 4940 & 12800 & 17740 & 0.6407 & 9.4973 & 10.1380 \\
\hline 4 & 4760 & 9560 & 14320 & 0.5322 & 2.2072 & 2.7394 & 24 & 5400 & 12520 & 17920 & 1.0000 & 8.5030 & 9.5030 \\
\hline 5 & 4480 & 9960 & 14440 & 0.3930 & 2.7092 & 3.1023 & 25 & 6240 & 12040 & 18280 & 2.0604 & 6.9933 & 9.0537 \\
\hline 6 & 4350 & 10090 & 14440 & 0.3392 & 2.8907 & 3.2299 & 26 & 3420 & 14920 & 18340 & 0.1019 & 20.4359 & 20.5378 \\
\hline 7 & 6860 & 7800 & 14660 & 3.3087 & 0.7980 & 4.1067 & 27 & 8440 & 10510 & 18950 & 9.3270 & 3.5446 & 12.8716 \\
\hline 8 & 6720 & 8360 & 15080 & 2.9845 & 1.1287 & 4.1132 & 28 & 4080 & 15040 & 19120 & 0.2462 & 21.2710 & 21.5172 \\
\hline 9 & 2740 & 12420 & 15160 & 0.0336 & 8.1688 & 8.2024 & 29 & 5400 & 13900 & 19300 & 1.0000 & 14.3424 & 15.3424 \\
\hline 10 & 7140 & 8380 & 15520 & 4.0413 & 1.1423 & 5.1836 & 30 & 7960 & 11840 & 19800 & 6.9598 & 6.4314 & 13.3912 \\
\hline 11 & 7640 & 7980 & 15620 & 5.6689 & 0.8945 & 6.5634 & 31 & 5700 & 14200 & 19900 & 1.3104 & 15.9585 & 17.2689 \\
\hline 12 & 2720 & 13030 & 15750 & 0.0324 & 10.3818 & 10.4142 & 32 & 6400 & 13760 & 20160 & 2.3385 & 13.6346 & 15.9730 \\
\hline 13 & 3240 & 13040 & 16280 & 0.0778 & 10.4217 & 10.4994 & 33 & 4620 & 15700 & 20320 & 0.4584 & 26.3662 & 26.8246 \\
\hline 14 & 4500 & 11980 & 16480 & 0.4019 & 6.8208 & 7.2226 & 34 & 6240 & 14200 & 20440 & 2.0604 & 15.9585 & 18.0189 \\
\hline 15 & 4040 & 12520 & 16560 & 0.2344 & 8.5030 & 8.7374 & 35 & 3060 & 17560 & 20620 & 0.0584 & 46.1500 & 46.2084 \\
\hline 16 & 3880 & 12980 & 16860 & 0.1915 & 10.1841 & 10.3756 & 36 & 7200 & 13460 & 20660 & 4.2140 & 12.2117 & 16.4256 \\
\hline 17 & 7200 & 9700 & 16900 & 4.2140 & 2.3736 & 6.5876 & 37 & 7720 & 13000 & 20720 & 5.9720 & 10.2628 & 16.2348 \\
\hline 18 & 7330 & 9800 & 17130 & 4.6084 & 2.4985 & 7.1069 & 38 & 5880 & 14840 & 20720 & 1.5308 & 19.8938 & 21.4246 \\
\hline 19 & 4520 & 12720 & 17240 & 0.4109 & 9.2042 & 9.6151 & 39 & 4980 & 15800 & 20780 & 0.6671 & 27.2166 & 27.8837 \\
\hline \multirow[t]{7}{*}{20} & 4080 & 13240 & 17320 & 0.2462 & 11.2458 & 11.4920 & 40 & 6740 & 14100 & 20840 & 3.0292 & 15.4044 & 18.4336 \\
\hline & & & & & & & 41 & 8100 & 13680 & 21780 & 7.5937 & 13.2428 & 20.8365 \\
\hline & & & & & & & & & Rata-rata & 17651.5 & 1.9541 & 10.4999 & 12.4539 \\
\hline & & & & & & & \multicolumn{4}{|c|}{$\begin{array}{l}\text { Beban sumbu berdasarkan rata-rata } \\
\text { EAL diatas }(\mathrm{kg})\end{array}$} & 6174.21 & 13059.51 & 19233.72 \\
\hline & & & & & & & \multicolumn{4}{|c|}{ Distribusi beban sumbu (\%) } & 32.10 & 67.90 & 100.00 \\
\hline & & & & & & & \multicolumn{4}{|c|}{ Distribusi beban sumbu(dibulatkan, \%) } & 32 & 68 & 100 \\
\hline & & & & & & & \multicolumn{4}{|c|}{$\begin{array}{l}\text { Distribusi beban sumbu( Bina Marga } \\
\text { 1987, \%) }\end{array}$} & 34 & 66 & 100 \\
\hline
\end{tabular}

Berdasarkan beban total kendaraan pada Tabel 2, maka nilai EAL untuk kendaraan dengan sumbu $1.2 \mathrm{H}$ adalah sebagai berikut,

\begin{tabular}{|c|c|c|c|c|c|c|}
\hline \multirow{2}{*}{$\begin{array}{c}1.2 \mathrm{H} \\
\text { Muatan } \\
\text { Over- } \\
\text { loaded }\end{array}$} & \multicolumn{2}{|c|}{$\begin{array}{l}\text { Distribusi Beban } \\
\text { (\%) }\end{array}$} & \multirow{2}{*}{$\begin{array}{c}\text { Beban } \\
\text { Total } \\
\text { Rata- } \\
\text { rata } \\
(\mathrm{kg})\end{array}$} & \multicolumn{3}{|c|}{ Hasil EAL } \\
\hline & $\begin{array}{l}\text { As } \\
\text { Depan }\end{array}$ & $\begin{array}{c}\text { As } \\
\text { Bela- } \\
\text { kang }\end{array}$ & & $\begin{array}{c}\text { As } \\
\text { Depan }\end{array}$ & $\begin{array}{c}\text { As } \\
\text { Bela- } \\
\text { kang }\end{array}$ & $\begin{array}{l}\text { Total } \\
\text { EAL }\end{array}$ \\
\hline Peneliti & $32 \%$ & $68 \%$ & 17651 & 1.2522 & 6.8865 & 8.1387 \\
\hline $\begin{array}{l}\text { Bina } \\
\text { Marga }\end{array}$ & $34 \%$ & $66 \%$ & 14000 & 0.5322 & 1.8617 & 2.3939 \\
\hline
\end{tabular}

Dari hasil kalkulasi EAL diatas, menyatakan bahwa terdapat hasil EAL yang perbedaannya cukup signifikan antara hasil penelitian dan Bina Marga. Nilai total EAL untuk kendaraan 1.2H dari hasil penelitian adalah sebesar 8,1387.
Nilai total EAL untuk kendaraan 1.2H dari Bina Marga adalah sebesar 2,3939. Dari perbandingan tersebut membuktikan bahwa nilai EAL hasil penelitian adalah 3,40 kali lebih besar dari Bina Marga 2005 dengan penggunaan nilai pangkat 5.

Kendaraan golongan 1.2+2.2 merupakan truk 2 sumbu dan trailer penarik 2 sumbu. Dengan sumbu depan termasuk jenis sumbu tunggal roda tunggal (STRT) dan 3 sumbu lainnya termasuk jenis sumbu tunggal roda ganda (STRG). Pada penelitian ini jumlah truk 1.2+2.2 dengan muatan overloaded sebanyak 27 truk Maka, perhitungan nilai VDF untuk truk $1.2+2.2$ adalah sebagai berikut:

VDF sumbu $1=\left[\frac{3380 / 1000}{5,4}\right]^{5}=0,0961$ 
$E A L$ sumbu $1=\frac{V D F 1+V D F 2+\ldots \ldots \ldots \ldots . . V D F 27}{n}=12.6037$

VDF sumbu $2=\left[\frac{7040 / 1000}{8,16}\right]^{5}=0,4780$

$E A L$ sumbu $2=\frac{V D F 1+V D F 2+\ldots \ldots \ldots \ldots . . V D F 27}{n}=27,3768$

VDF sumbu $3=\left[\frac{11340 / 1000}{8,16}\right]^{5}=5.1834$

$E A L$ sumbu $3=\frac{V D F 1+V D F 2+\ldots \ldots \ldots \ldots . . V D F 27}{n}=21,3746$

\begin{tabular}{ccccc} 
& \multicolumn{3}{c}{ Distribusi Beban (\%) } \\
$\begin{array}{c}\text { 1.2+2.2 } \\
\text { Muatan }\end{array}$ & \multicolumn{2}{c}{ Truk } & \multicolumn{2}{c}{ Trailer } \\
Overloaded & As & As & As & As \\
& Depan & Belakang & Depan & Belakang \\
Penelitian & $17 \%$ & $30 \%$ & $28 \%$ & $25 \%$ \\
Bina Marga & $16 \%$ & $36 \%$ & $24 \%$ & $24 \%$
\end{tabular}

Dari hasil kalkulasi EAL diatas, menyatakan bahwa terdapat hasil EAL yang perbedaannya cukup signifikan antara hasil penelitian dan Bina Marga. Nilai total EAL untuk kendaraan 1.2+2.2 dari hasil penelitian adalah sebesar 24,9257. Nilai total EAL untuk kendaraan 1.2+2.2 dari Bina Marga adalah sebesar 7.1424. Dari perbandingan tersebut membuktikan bahwa nilai EAL hasil penelitian adalah 3,49
$V D F$ sumbu $4=\left[\frac{9840 / 1000}{8,16}\right]^{5}=2,5499$
EAL sumbu $4=\frac{V D F 1+V D F 2+\ldots \ldots \ldots \ldots . . . V D F 27}{n}=11,1671$

Untuk lebih lengkapnya, perhitungan VDF dari masingmasing kendaraan dapat dilihat pada Tabel 4.

Berdasarkan beban total kendaraan pada Tabel 2, maka nilai EAL untuk kendaraan dengan sumbu $1.2 \mathrm{H}$ adalah sebagai berikut:

\begin{tabular}{|c|c|c|c|c|}
\hline \multicolumn{5}{|c|}{ Hasil EAL } \\
\hline \multicolumn{2}{|c|}{ Truk } & \multicolumn{2}{|c|}{ Trailer } & \\
\hline $\begin{array}{c}\text { As } \\
\text { Depan }\end{array}$ & $\begin{array}{c}\text { As } \\
\text { Belakang }\end{array}$ & $\begin{array}{c}\text { As } \\
\text { Depan }\end{array}$ & $\begin{array}{c}\text { As } \\
\text { Belakang }\end{array}$ & $\begin{array}{l}\text { Total } \\
\text { EAL }\end{array}$ \\
\hline 4.4642 & 9.6968 & 6.8677 & 3.8969 & 24.9257 \\
\hline 0.6971 & 5.1016 & 0.6718 & 0.6718 & 7.1424 \\
\hline
\end{tabular}

kali lebih besar dari Bina Marga 2005 dengan penggunaan nilai pangkat 5 .

Dari analisis nilai distribusi hasil EAL antara hasil penelitian dengan Bina Marga, selanjutnya dilakukan uji hipotesis rata-rata menggunakan program SPSS. Hasil uji rata-rata dua sampel independen menggunakan program SPSS untuk kendaraan 1.2H dan 1.2+2.2 dapat dilihat pada Tabel 5.

Tabel 5. Hasil uji rata-rata kendaraan $1.2 \mathrm{H}$

\begin{tabular}{|c|c|c|c|c|c|c|c|c|c|}
\hline \multirow{3}{*}{$\begin{array}{c}\text { Tipe } \\
\text { Kendaraan }\end{array}$} & \multicolumn{2}{|c|}{$\begin{array}{l}\text { Lavene's Test for } \\
\text { Equality of variances }\end{array}$} & \multicolumn{7}{|c|}{ t-test fo Equality of Means } \\
\hline & \multirow[t]{2}{*}{$1+5$} & \multirow[t]{2}{*}{ Sig, } & \multirow[t]{2}{*}{$\mathrm{t}$} & \multirow[t]{2}{*}{ df } & \multirow[t]{2}{*}{$\begin{array}{l}\text { Sig. (2- } \\
\text { tailed) }\end{array}$} & \multirow[t]{2}{*}{$\begin{array}{c}\text { Mean } \\
\text { Difference }\end{array}$} & \multirow[t]{2}{*}{$\begin{array}{l}\text { Std. Error } \\
\text { Difference }\end{array}$} & \multicolumn{2}{|c|}{$\begin{array}{l}\text { 95\% Confidence } \\
\text { Interval of the } \\
\text { Difference }\end{array}$} \\
\hline & & & & & & & & Lower & Upper \\
\hline $1.2 \mathrm{H}$ & 125.069 & .000 & 7.694 & 40. & .000 & 6.84372 & 88950 & 5.04597 & 8.64146 \\
\hline $1.2+2.2$ & 56.349 & .000 & 4.377 & 26. & 000 & 30.71234 & 7.01698 & 16.28872 & 45.13595 \\
\hline
\end{tabular}

Dari hasil pengujian menggunakan program SPSS pada Tabel 5 menyebutkan bahwa nilai P-value $<0,05$ yang menyatakan Ho ditolak dan $\mathrm{H}_{1}$ diterima. Dengan penolakan Ho tersebut, maka asumsi nilai distribusi berbeda diterima. Sehingga dapat diambil kesimpulan bahwa ada perbedaan nilai distribusi antara hasil penelitian dengan nilai distribusi dari pedoman Bina Marga. Perbedaan nilai distribusi berpengaruh terhadap besaran nilai EAL.

\section{Simpulan}

Terdapat perbedaan antara nilai distribusi beban as kendaraan dari hasil penelitian dan dari pedoman yang sudah ada pada Bina Marga 1987. Berikut adalah hasil yang didapatkan dari penelitian dari kendaraan dengan muatan overloaded:
1. Nilai EAL kendaraan $1.2 \mathrm{H}$ muatan overloaded adalah 3,40 kali lebih besar dari Bina Marga.

2. Nilai EAL kendaraan 1.2+2.2 muatan overloaded adalah 3,49 kali lebih besar dari Bina Marga.

Perbedaan nilai distribusi tersebut membuktikan bahwa nilai distribusi yang ada pada pedoman kurang memperhitungan kendaraan dengan muatan yang overloaded. Nilai distribusi yang berbeda mempengaruhi besaran nilai EAL, sehingga mempengaruhi hasil dari perencanaan perkerasan lentur. Hal ini dapat menyebabkan kinerja perkerasan kurang optimal dan menyebabkan perkerasan mengalami kerusakan dini. 
Tabel 4. Distribusi beban as dan nilai EAL untuk truk 1.2+2.2

\begin{tabular}{|c|c|c|c|c|c|c|c|c|c|c|}
\hline \multirow{3}{*}{ No } & \multicolumn{5}{|c|}{ Distribusi Beban As (kg) } & \multicolumn{5}{|c|}{ Hasil EAL (Bina Marga 2005) } \\
\hline & \multicolumn{2}{|c|}{ Truk } & \multicolumn{2}{|c|}{ Trailer } & \multirow[b]{2}{*}{ Total } & \multicolumn{2}{|c|}{ Truk } & \multicolumn{2}{|c|}{ Trailer } & \multirow[b]{2}{*}{ Total } \\
\hline & $\begin{array}{c}\text { As } \\
\text { Depan }\end{array}$ & $\begin{array}{c}\text { As } \\
\text { Belakang }\end{array}$ & $\begin{array}{c}\text { As } \\
\text { Depan }\end{array}$ & $\begin{array}{c}\text { As } \\
\text { Belakang }\end{array}$ & & As Depan & $\begin{array}{c}\text { As } \\
\text { Belakang }\end{array}$ & $\begin{array}{c}\text { As } \\
\text { Depan }\end{array}$ & $\begin{array}{c}\text { As } \\
\text { Belakang }\end{array}$ & \\
\hline 1 & 3380 & 7040 & 11340 & 9840 & 31600 & 0.0961 & 0.4780 & 5.1834 & 2.5499 & 8.3074 \\
\hline 2 & 3700 & 8240 & 9740 & 10120 & 31800 & 0.1510 & 1.0500 & 2.4229 & 2.9339 & 6.5579 \\
\hline 3 & 2540 & 6200 & 11760 & 11600 & 32100 & 0.0230 & 0.2532 & 6.2171 & 5.8055 & 12.2988 \\
\hline 4 & 3360 & 5600 & 8060 & 16360 & 33380 & 0.0933 & 0.1522 & 0.9402 & 32.3941 & 33.5798 \\
\hline 5 & 3840 & 7660 & 8900 & 13280 & 33680 & 0.1818 & 0.7289 & 1.5435 & 11.4167 & 13.8709 \\
\hline 6 & 5760 & 11320 & 16760 & 1780 & 35620 & 1.3808 & 5.1378 & 36.5527 & 0.0005 & 43.0719 \\
\hline 7 & 4740 & 9180 & 10800 & 11020 & 35740 & 0.5211 & 1.8020 & 4.0613 & 4.4922 & 10.8766 \\
\hline 8 & 5340 & 9960 & 12820 & 9700 & 37820 & 0.9457 & 2.7092 & 9.5717 & 2.3736 & 15.6002 \\
\hline 9 & 6880 & 15680 & 10120 & 5940 & 38620 & 3.3572 & 26.1987 & 2.9339 & 0.2044 & 32.6942 \\
\hline 10 & 9800 & 13560 & 11240 & 4820 & 39420 & 19.6862 & 12.6721 & 4.9588 & 0.0719 & 37.3890 \\
\hline 11 & 5940 & 15800 & 10380 & 7360 & 39480 & 1.6105 & 27.2166 & 3.3307 & 0.5970 & 32.7548 \\
\hline 12 & 7660 & 14120 & 7800 & 10160 & 39740 & 5.7435 & 15.5140 & 0.7980 & 2.9924 & 25.0479 \\
\hline 13 & 5760 & 10120 & 9560 & 14340 & 39780 & 1.3808 & 2.9339 & 2.2072 & 16.7608 & 23.2828 \\
\hline 14 & 6220 & 12580 & 12460 & 8640 & 39900 & 2.0276 & 8.7087 & 8.3012 & 1.3308 & 20.3683 \\
\hline 15 & 6900 & 11140 & 7000 & 16120 & 41160 & 3.4063 & 4.7421 & 0.4646 & 30.0867 & 38.6996 \\
\hline 16 & 5060 & 15400 & 6560 & 15420 & 42440 & 0.7224 & 23.9416 & 0.3358 & 24.0974 & 49.0972 \\
\hline 17 & 6180 & 10840 & 16040 & 9440 & 42500 & 1.9632 & 4.1371 & 29.3475 & 2.0721 & 37.5199 \\
\hline 18 & 5660 & 14040 & 16160 & 9060 & 44920 & 1.2651 & 15.0794 & 30.4618 & 1.6873 & 48.4936 \\
\hline 19 & 5700 & 14100 & 15380 & 10380 & 45560 & 1.3104 & 15.4044 & 23.7865 & 3.3307 & 43.8320 \\
\hline 20 & 8720 & 19140 & 17760 & 520 & 46140 & 10.9803 & 71.0001 & 48.8387 & 0.0000 & 130.8191 \\
\hline 21 & 10880 & 11360 & 16440 & 14460 & 53140 & 33.2029 & 5.2293 & 33.1939 & 17.4739 & 89.1000 \\
\hline 22 & 11160 & 23560 & 17840 & 760 & 53320 & 37.7009 & 200.6438 & 49.9486 & 0.0000 & 288.2933 \\
\hline 23 & 3960 & 21230 & 12860 & 15740 & 53790 & 0.2121 & 119.2063 & 9.7220 & 26.7038 & 155.8441 \\
\hline 24 & 4760 & 15280 & 14220 & 19880 & 54140 & 0.5322 & 23.0232 & 16.0712 & 85.8284 & 125.4550 \\
\hline 25 & 9860 & 14580 & 19120 & 11680 & 55240 & 20.2962 & 18.2111 & 70.6299 & 6.0085 & 115.1457 \\
\hline 26 & 11110 & 13240 & 18620 & 14900 & 57870 & 36.8639 & 11.2458 & 61.8654 & 20.2993 & 130.2743 \\
\hline \multirow[t]{3}{*}{27} & 14800 & 21320 & 21020 & 760 & 57900 & 154.6464 & 121.7546 & 113.4260 & 0.0000 & 389.8270 \\
\hline & & & & Rata-rata & 42844 & 12.6037 & 27.3768 & 21.3746 & 11.1671 & 72.5223 \\
\hline & \multicolumn{5}{|c|}{ Beban sumbu berdasarkan rata-rata EAL diatas (kg) } & 8963.83 & 15818.55 & 15054.62 & 13221.42 & 53058.43 \\
\hline \multicolumn{6}{|c|}{ Distribusi beban sumbu (\%) } & 16.8943 & 29.8135 & 28.3737 & 24.9186 & 100 \\
\hline \multicolumn{6}{|c|}{ Distribusi beban sumbu(dibulatkan, \%) } & 17 & 30 & 28 & 25 & 100 \\
\hline \multicolumn{6}{|c|}{ Distribusi beban sumbu( Bina Marga 1987, \%) } & 16 & 36 & 24 & 24 & 100 \\
\hline
\end{tabular}

\section{Daftar Pustaka}

[1] B. M. Departemen Pekerjaan Umum, "Perencanaan Tebal Lapis Tambah Perkerasa Lentur dengan Metoda Lendutan,” 2005.

[2] M. Yoder, EJ \& Witczak, Principles of Pavement
Design, 2nd Edition. USA, 1975.

[3] I. B. Mochtar, "Masalah Kerusakan Dini(Premature Deterioration) pada Jalan-Jalan Raya di Indonesia,” in Prosiding Lokakarya tentang Jembatan-Timbang. Surabaya 23 Maret., 1990. 
[4] C. A. Prastyanto and I. B. Mochtar, "The effect of overloaded heavy vehicles on the values of axle load distribution, tire pressure and equivalent axle load (case study: Jenu-Tuban Aterial Road, East Java, Indonesia),” ARPN J. Eng. Appl. Sci., vol. 11, no. 24, pp. 14354-14360, 2016.

[5] Kementrian Pekerjaan Umum dan Perumahan Rakyat, “Manual Desain Perkerasan Jalan,” 2017. 
